\title{
Celebrating the sacrament of Holy Communion during COVID-19: A Methodist perspective
}

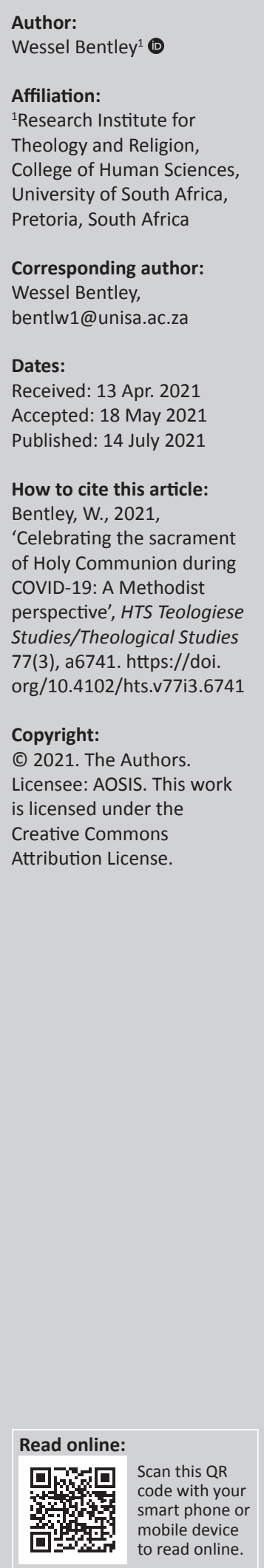

Author:

Affiliation

${ }^{1}$ Research Institute for University of South Africa,

Corresponding author: Wessel Bentley,

Dates:

Received: 13 Apr. 2021

Accepted: 18 May 2021

How to cite this article:

Bentley, W., 2021, COVID-19: A Methodist perspective', HTS Teologiese 77(3), a6741. https://doi.

Copyright:

C 2021. The Authors is licensed under the Creative Commons Attribution License. mobile device to read online.
This article forms part of the change agents special collection. It investigates the way the Methodist Church of Southern Africa (MCSA) has engaged the question of practicing Holy Communion in the context of the coronavirus disease 2019 (COVID-19) lockdown. Mainly using communiques by the Office of the Presiding Bishop and contributions made by clergy and laity on the practice of online worship services, and Holy Communion in particular, the article not only describes points of contention but also matters for consideration in balancing church polity whilst being contextually present and relevant. The article then celebrates the work of the Doctrine, Ethics and Worship Commission (DEWCOM) of the MCSA in potentially providing a way forward for the denomination that holds polity and relevance together in meaningful tension.

Contribution: This research contributes to the ongoing dialogue within the Methodist Church of Southern Africa on how the sacrament of Holy Communion should be practiced in the context of a social lockdown as precipitated by the COVID-19 pandemic.

Keywords: Holy Communion; Methodism; COVID-19; lockdown; sacrament.

\section{Introduction}

On 23 March 2020, in response to the coronavirus disease 2019 (COVID-19) pandemic, South African President Cyril Ramaphosa announced that commencing from 27 March 2020, the country was to go into a 21-day nationwide lockdown. It was initially hoped that the lockdown was going to be a short-term exercise, a national effort to lower the rate of new infections and life was to return to normal once there was some measure of control over this illness. It soon became clear that the pandemic was beyond containment and that lockdown was going to be a protracted process. Although the lockdown had a significant impact on the rate of infections in the country, the duration of the lockdown (albeit at different levels ranging from full lockdown to the intermittent easing of restrictions) has now lasted over a year, with the third and possible future waves of infections looming in the not too distant future. Besides the impact the pandemic has had on the economy, and the psychological and life experiences of the global population, religious communities too had to adapt to a 'new normal'. As a minister of religion, the author admits that the impact of COVID-19 on the function and processes of the church has been more severe than initially expected.

Almost overnight, churches and other places of worship had to adopt new strategies of ministry in order to maintain a sense of community, whilst adhering to health protocols provided by the state. ${ }^{1}$ Congregations were initially not allowed to gather, funerals became possible superspreader events, and thus had to be limited to small, short and controlled services where people said farewell to their loved ones in a rather rushed and unfamiliar manner. Weddings were either put on hold or had to adapt to the health protocols imposed by government to ensure safe celebrations for all in attendance. Whenever possible, some congregations were able to mobilise online services to maintain some sense of normality for their communities. All these measures had their own level of effectiveness, successes and failures. Other congregations that did not have access to online services (or even electricity in rural areas) were not as fortunate to keep their congregations together for times of worship. Churches across the board literally had to adapt on-the-go as lockdown

1.'The Church had to find expression in a fundamentally different reality where the doors of the sanctuary were shutdown resulting in the inability to gather in a building in the normal way. Coronavirus disease 2019 pandemic challenged or exposed the complacency or limitation of the Church, whose life is over reliant on the Sunday building gathering as a way of life. The strength of the Church was locked down and a guaranteed place of worship and loyal constituency was closed for the community of believers. Everyone, including Christian believers started questioning the relevance of the Church. What made the situation worse is that priests were declared non-essential except when there was death' (Mothlodi 2020:1).

Note: Special Collection: Being a Change Agent in a (Post-) Covid South Africa, sub-edited by Erna Oliver (University of South Africa). 
was imposed, prolonged and subjected to changing protocols as the rate of infections fluctuated. Out of all the adaptations for worship, it was probably the celebration of the church's sacraments, specifically that of Holy Communion, that proved to be the most challenging. This article reflects on the process in which the Methodist Church of Southern Africa (MCSA), in particular, navigated (and still proceeds to do so), the murky waters of holding its teaching of the celebration of Holy Communion in tension with the unique context it finds itself in.

Nothing to date has been written and published in academic journals and books on how this particular denomination is to define and practice an adapted sacrament of Holy Communion in this or any other extraordinary context and so the author has depended mainly on the regular communiques from the Office of the Presiding Bishop that have been distributed to ministers and congregations throughout the Methodist Connexion. This article also engages some discussion articles that were presented by ministers and academics on the MCSA's Doctrine, Ethics and Worship Commission's online platform (these have been made available on the MCSA's official website and cited accordingly). The communiques and presentations outline the different theological, ethical and moral struggles that the denomination has to navigate in order to maintain a sense of orthodoxy in its praxis, whilst being pragmatic in a highly volatile and unique situation.

\section{An unexpected and contentious problem}

The matter of how to celebrate the sacrament of Holy Communion caught everybody off-guard. This is evident in the early communiques sent out by the Presiding Bishop of the MCSA, where they did not once refer to procedures and practices for this sacrament. The first communication about procedures and practices for worship pertaining to the COVID-19 pandemic was sent out on 16 March 2020 (Malinga 2020a), preceding the lockdown announcement by President Ramaphosa. In this letter, the Presiding Bishop, in consultation with the District bishops of the MCSA encouraged congregations to start planning their worship services around the following guidelines:

- no more than 100 congregants to attend a worship service

- to practice social distancing and to adhere to high hygiene protocols $^{2}$

- ministers to stay informed regarding the pandemic and to give their congregants regular updates

- to encourage those who tested positive for COVID-19, to self-isolate and to support them and their families

- to encourage e-worship services, rather than physical gatherings

- sanitise churches and furniture regularly

- postpone conventions and other events that carry the potential for high attendance.

2.At this point, the "trinity" of health protocols, namely wearing a mask, sanitising and social distancing had not been formalised in public discourse.
Although the letter called on ministers and congregations to postpone baptisms with immediate effect, it did not address the question of Holy Communion at all. In my estimation, this was not an oversight, but an honest assumption that a looming lockdown was not going to last long and therefore no drastic interventions were necessary.

Shortly after the dissemination of this communication, almost all of the countries that comprise the MCSA Connexion announced national lockdowns. ${ }^{3}$ In a communique sent out on the 25 March 2020 (after it became clear that all these countries were soon to be under lockdown), the Office of the Presiding Bishop called on all Methodists through the Connexion to cease gathering for worship and for ministers to '...ensure that creative methods are used to maintain worship and prayer within our communities' (Malinga 2020b). Once again, practices to be followed were not specifically mentioned in the celebration of Holy Communion. After the first month of lockdown and knowing that lockdown restrictions were not going to be lifted completely within the foreseeable future, ministers, using social media platforms, started to query the church's position on Holy Communion and whether it is feasible to celebrate the sacrament online. Initial responses from the district bishops indicated that ministers should rather not celebrate the sacrament online and that further consultation was needed (Mokgothu 2020). Weeks went by and the countries forming part of the MCSA showed signs of decreasing rates of infection, beckoning the easing of lockdown restrictions.

President Ramaphosa (and his counterparts in other Southern African countries) then indeed announced that lockdown restrictions were set to be eased as of 01 June 2020. To this news, the Office of the Presiding Bishop and General Secretary of the MCSA issued another communique on 27 May 2020 (Malinga \& Hansrod 2020), encouraging congregations to proceed with caution when considering a return to physical services and suggesting that congregations continue to proceed with online worship services where possible. By this time, the debate around Holy Communion was already a contentious topic amongst clergy, sparking the MCSA's Doctrine, Ethics and Worship Commission to host a series of webinars, addressing the nature, function and processes of the MCSA during the COVID-19 pandemic. On 13 May 2020, the discussion focussed solely on the sacrament of Holy Communion, eliciting a range of contributions by ministers, academics and laity, all contributing to the vocalisation of the need for Holy Communion, but cautious as to how it should be regulated and practiced. On one point, all participants were clear, namely that Holy Communion is an indispensable part of the church's life and identity and fundamental to the expression of Methodist spirituality.

Rev. Olivier (2020) articulated this point succinctly by stating:

3.Lockdown commenced on the following dates: Swaziland - 28 March, Namibia - 28 March, Lesotho - 29 March, Mozambique - 01 April and Botswana -02 April. 
For Methodists, Holy Communion is not just seen as a Holy Sacrament ordained by Jesus Christ Himself at the Last Supper, but through Wesleyan theology we view it as a means of grace that should be shared regularly as it provides 'indispensable nourishment for the soul'. ${ }^{4}$ (p. 1)

The contentious aspect of the conversation centred around the actual practice of what was labelled 'virtual Communion services', whereby the sacrament is celebrated on various online platforms. The divergent perspectives will be described later in this article but it suffices to say that the one pronounced point was on the seemingly exclusive nature of virtual Holy Communion, as many persons and households either do not have access to online platforms or do not have the resources available to make them part of the online worshipping community.

Dr Phemelo Marumo, a specialist in missiology raised the concern that only those who have access to online facilities, and who have access to data are able to first, participate in online worship activities and then also by extension, to celebrate the sacrament of Holy Communion. This exclusive reality is, according to Marumo (2020), contrary to the very inclusive intention of the Lord's Table, where everyone should have access to participate (pp. 1-2). ${ }^{5}$ It was asked to continue to celebrate the sacrament of Holy Communion (a central part of its identity and worship), but if it used online platforms, many people would be excluded because of socioeconomic or other factors.

Lockdown highlighted the socio-economic disparities not only in civil society but also in the church. Reflecting on the lived experiences of people in the context of lockdown, Moeketsi (2020) stated:

During the lockdown, some were excited about binge-watching their favourite shows on Netflix, while others had to work two jobs and trying to home school their kids. Some were angry; some are bored; some are terrified at the possibility of losing their jobs, and some are trapped inside a house with someone abusive. ${ }^{6}$ Others had enough savings and others could barely make it past the first week of the lockdown. (p. 2)

Add to this, the luxury of some people being able to meet with fellow congregants online, whilst others experienced even greater isolation, loneliness and abandonment when the church, which usually offers some space for community, carries on worshipping and feasting around the Lord's Table without them. To this end, theologians such as Khuzwayo and others called on the church to critically engage the theological and moral implications if it were to continue to celebrate the sacrament of Holy Communion online. Khuzwayo (2020) made the point that in this context, where many people are excluded from worship and celebrating

\footnotetext{
4.Olivier cites Carder (2009:86) for this quote
}

5.See Stamm (2006) on the Methodist Church's teaching on an Open Table, referring to the emphasis in Methodist theology of being inclusive of all who desire to participate in the Sacrament of Holy Communion.

6.The problem of gender-based violence was certainly exacerbated by lockdown with especially women and children bearing the brunt of violence in the household (Jibiliza 2020:3-4)
Holy Communion, ministers are not at liberty to invent their own liturgies and means of celebrating the sacrament before it had been sanctioned by the church. Furthermore, congregations cannot call the virtual practice of Holy Communion a true representation of our belief but should rather resort to another recognised practice in the MCSA (and other Christian traditions), namely that of the Love Feast (see The Methodist Church of Southern Africa 2016:25, 88 ), where laity can break bread in their own homes as a symbol of Christian love and unity without the elements needing to be consecrated.

The counterargument is equally valid. What if congregations are able to meet online; should they be prohibited from celebrating the sacrament together? Is there ever a situation where someone is not excluded from the Lord's Table, for example, when people are unable to be physically present at a church service because of travel, illness or any other personal reason that does not essentially exclude them from being part of the community? Should the Table always be a Table-in-wait, until everyone is able and capable of being present?

Mothlodi (2020:2) was correct in stating that there is no one-size-fits-all solution to the problem of celebrating the sacrament of Holy Communion in the context of the COVID-19 lockdown. This is because 'The Church is not a homogeneous but a heterogenous entity' (Mothlodi 2020:2). For this reason, a complex dilemma such as the celebration of Holy Communion in this context is almost impossible to legislate and the church is challenged to find creative means in order to meet the desire of all who wish to continue to be in sacramental unity. So, how is the MCSA to move forward?

\section{Regulations around the sacrament}

The COVID-19 pandemic is certainly not the first to be faced by the Church (Kondile 2020:1) - this may be true, but the church in history has left very little guidance as to how it managed to continue the sacrament as a means of keeping people together during similar situations. In previous pandemics, churches became quarantine centres (Marumo 2020:3), with its presence felt in the midst of those affected. The author is unable to trace any documentation on how the church navigated the practice of Holy Communion whilst people were in the throes of, for instance the Spanish flu pandemic in the early 20th century. Be that as it may, now with the possibility of remote worship by means of e-platforms, the church's position is unrecognisably different. Churches cannot (by law) offer physical refuge to those infected and affected by COVID-19. Rather than a physical place of refuge, the continuation of the church's worship and service depends on its ability to adapt to contextual circumstances.

This said, the church still has polity to adhere to (or change). As it stands, the Methodist Book of Order is clear in its 
description of the meaning and practice of Holy Communion (The Methodist Church of Southern Africa 2016:15-19):

In Holy Communion the people of God of every time and place become united with God and with each other. They remember the death and celebrate the resurrection of Jesus Christ, through which they receive forgiveness for their sins and the salvation of their souls. (p. 15)

As such, polity directs that the sacrament should be celebrated regularly (The Methodist Church of Southern Africa 2016:15), and thus a prolonged absence from the Lord's Table, especially noting the potential for continued online worship services, is already a complication in the nature of Methodist expressions of worship.

The urgency of celebrating the sacrament brings forth certain questions. The first matter of interest is that the MCSA's polity directs that either an ordained minister or a probationer (authorised to administer the sacraments) may act as celebrant of the sacrament (The Methodist Church of Southern Africa 2016:15). This means that the celebrant is the one who is authorised (by the church) to consecrate the elements. For all practical means and purposes, the celebrant distributes elements consecrated at one Table. ${ }^{7}$ The objection to virtual celebrations of Holy Communion suggests two possible problems in polity. Firstly, the elements in people's homes do not come from one common Table. The question can be asked whether these elements have indeed been consecrated? Secondly, it may be possible for congregants who do not have access to online services, but who know that their fellow congregants are celebrating the sacrament, to take matters into their own hands and 'consecrate' the elements themselves. Where does this leave us theologically in terms of the embodiment of Christ in the sacrament, church unity, or even the doctrine of ordination?

On these concerns, it is understandable that some may call for the cessation of online Holy Communion as it constitutes 'through legislation, polity or church law, ... a "different or un-regulated" way of doing Holy Communion' (Olivier 2020:1). To this, Rev. Dr Scholtz (2020) responds:

Under 'Duties of Ministers', our Book of Order states the following: 'Ministers are to be servants of all Christ's people by being pastors to them in their homes and in every other situation'. (The Methodist Book of Order, 12th ed., para.4.73., p.41.) The current extraordinary situation of a global Covid-19 pandemic with all its attendant health, economic and social consequences is placing a significant demand upon the pastoral care that ministers are being called to exercise. ${ }^{8}$ (p. 2)

To Scholtz, the celebration of Holy Communion through online platforms is not a new norm to be implemented

7.The Methodist Service book (Methodist Conference Office 1975), which is a common liturgy used for the celebration of Holy Communion emphasises the act of the Fraction taking place around one Table. Scholtz (2020:2) made the point that the Fraction is a symbolic event through which the Church partakes of the that the Fraction is a symbolic event through which the Church partakes of the one Body and share in the one Cup. The symbolic nature of the Fraction may not necessarily have to be a literal breaking and sharing of one loaf. Already, where congregations use communion wafers, or pieces of bread, may not emanate from
the loaf used by the celebrant in the Fraction.

8.The Book of Order is in this article referenced as (The Methodist Church of Southern Africa 2016). universally, even in a post-COVID church, but is an immediate pastoral act by which presbyters perform the duties to which they were called. So, how can ministers consecrate the elements and have virtual services? One of the practical suggestions offered was that a minister could consecrate the elements beforehand and that these be distributed in a way 'feasible and permissible under lockdown regulations' (Caba 2020:3). Some congregations indeed made this possible by having pre-packed consecrated elements that could be collected from the church during the course of the week preceding a communion service. The congregation could then all celebrate the sacrament, knowing that they were in possession of consecrated elements. But this, too, had problems. What if people forgot or were unable to collect consecrated elements from church? Are they then to participate in the watching of an online service, but refrain from participating in the sacrament?

Is it important for the celebrant, the elements and the congregation to be in the same physical space in order for Holy Communion to be celebrated in a liturgically correct manner? Silolo and Olivier, respectively, make an interesting point, stating that the MCSA's polity does not specify the proximity of the celebrant, the elements or the congregation (Olivier 2020:3; Silolo 2020:2) and that the virtual presence of a congregation or of the celebrant and the elements should be enough to justify the practise of virtual Communion. Although this is an interesting point, one could argue that the omission of a directive indicating the proximity of celebrant, elements and congregation does not necessarily justify the physical distance between them in virtual space; church polity on Holy Communion assumes that the status quo for Holy Communion is a physical gathering, where the celebrant, elements and congregation are present as an act of community and communion and therefore does not need to explicitly specify locality.

Coronavirus disease 2019 lockdown, however, is a unique situation, and as Dr Martin Mostert (2020) commented:

If Holy Communion is only valid if practiced in the same physical space, then in the context of COVID-19 '...effectively this means that the sacrament, like alcohol and tobacco, is not available to Methodists under Lockdown conditions'. (p. 1)

\section{What would be in the church's best interest?}

Noting that COVID-19 lockdown offers a unique set of circumstances, Rev. Mzwandile Molo reminded the church that there is a fundamental difference between how things ought to be done and what is practically feasible in a particular (and in this case, a very unique) context (Molo 2020:1-2). Instead of arguing about the nitty-gritty of church doctrine and polity (which needs to be done, of course, but not to the extent that it paralyses the church), the question should be asked as to how Holy Communion could be a gift in the midst of a crisis (Molo 2020:1). Communion, after all, is not so much about ritual as it is about community. 
The Methodist Book of Order itself highlights this point (The Methodist Church of Southern Africa 2016):

\begin{abstract}
As we have communion with Christ, so also we have communion with one another. The whole Church is involved in each local celebration. By partaking of the one loaf and the common cup around the same table at the invitation of the same Lord, we are built up as members of His one undivided body, and called to care for, and suffer and rejoice with, all other members in love. Thus Christ joins us together in one new humanity in which the barriers that divide us in this age are broken down. (p. 16)
\end{abstract}

Silolo (2020:3) argued that virtual Holy Communion services can achieve just that. The barrier that divides us in this context is the COVID-19 pandemic, which forces people apart. The very act of celebrating a sacrament that reminds us of our unity with God and each other, even via online platforms, should therefore be seen as a unifying act of resistance. It protests against the pandemic's divisive consequences, making it possible for congregations to be together, even though not in the same physical location. Silolo (2020:3) further argued that doctrine is never static but should be contextually relevant. In the context of COVID-19 lockdown, the doctrine on the celebration of Holy Communion cannot presume to dictate practice as if there were no lockdown at all. To this end, for the church to respond effectively, it needs to 'stretch its imagination and language' (Moeketsi 2020:4).

It is not as if the church has been in the same static doctrinal position since its inception. Church history is full of challenges where context (and new information) drove changes in doctrine and praxis. One could cite examples of this in, for instance, the Copernican revolution of worldviews, the Reformation, Darwin's contribution to evolutionary biology, the evolving understanding of marriage, sexuality, ordination and the list goes on. Has COVID-19 sparked a digital revolution in the church, whereby not even a global pandemic can prevent the church from celebrating a unifying sacrament? If we answer 'Yes', then the tone of the conversation on the permissible conditions for celebrating the sacrament becomes less pronounced, moving rather to a focus on the building and strengthening of communities. One gets the sense that even ecumenical movements, such as the South African Council of Churches (SACC) grabbed the opportunity of renewed forms of worship to inspire hope, rather than to impose punitive sanctions for unorthodox innovation. As the church celebrated its first Christmas under COVID-19 lockdown, fearing that gatherings could spark renewed outbreaks, the SACC issued a statement, urging 'churches to do all they can to preserve life' and to 'assume a state of war and restrain ourselves to save lives' (South African Council of Churches 2020). The aim here is not orthodoxy or orthopraxis, but celebrating the sanctity of life, even if itmeans that the church should act counterintuitively, namely not to gather (physically).

But, as Tapula (2020:2) reminded us again, although online services should be the immediate goal, and could be a model for future formats of worship, the church '...should be cognisant of those who are unable to access the internet...', those who are automatically excluded for reasons mentioned before in this article. For the time being, it seems as if online celebrations of the sacrament of Holy Communion meet a contextual need, but it cannot be the norm once we move back to a sense of normality.

\section{A virtue rather than a vice}

It is as if the COVID-19 pandemic has given the entire world, including the church a wake-up call. We must rethink economy and especially economic disparity. We are reminded that we are not an indispensable species, but that we are tasked with a tremendous responsibility to act as stewards of this planet. We must rethink work, travel, food security and sustainability, family, relationships, and in the context of this article, the church and its sacraments. Molo resonates with this point, arguing that COVID-19 has moved our focus on spirituality away from locality and towards a sense of belonging. He makes the following point (Molo 2020):

It is my suspicion that this is a reminder what our people are looking for during this time of COVID-19. When they miss the church, I suspect they do not miss the bricks and mortar. They miss that community that invites them just as they are to the presence of that wounded love that embraces them not only because they are sinners but also because their pain is known and transformed in the woundedness of the Lord and centre of that Community. It is my suspicion that when our people long for Holy Communion they do not long for the bread and the wine in an empty ritualistic performance. (p. 4)

It is in the context of community that the church finds its identity and not the other way around (Moeketsi 2020:2). It is because the community exists, that the church can adapt its practices so that the community can find hope, peace and love through its existence and its practices. The celebration of Holy Communion, even if it is through online platforms, ministers to the community, and is not aimed at merely maintaining and protecting the church as an institution or its traditions. The church's ministers, in turn, serve people, and by doing so witness to the love of God. 'Every pandemic heightens the need for the church to give expression to how God enters the suffering of the world as a participant in its economic and social life' (Moeketsi 2020:3). This means that virtual celebrations of the sacrament of Holy Communion cannot and may not be limited to the online participants, but become the missional imperative for the church to reach out to those who need Holy Communion (and all it represents) the most.

Magruder (2020) challenged the church precisely on this point:

Throughout the world, there are spiritually hungry people who have been unable to gather at the Table for spiritual sustenance. The question that faced Wesley faces us again: What can be done to meet the growing need for communion? (p. 2)

The church needs to find a way to move forward in creative and meaningful ways so that the message of Holy Communion cannot get lost in either apathy or doctrinal rigidity. 


\section{Administering the sacrament in a new way}

If the church is unable to respond creatively and meaningfully in the context of COVID-19 lockdown, it will lose its prophetic witness and its credibility amongst those who have found in it a safe-haven for maintaining religious presuppositions. 'The inability to gather does not and should not suggest that the church is irrelevant, non-essential or provide nonessential service'. (Mothlodi 2020:3). It is imperative, even as the church contemplates its own practices of the sacraments that it undertakes a process of renewal and revitalisation. Renewal is key to the survival of the church; it cannot be locked in religious dogmatisms, even when these have a significant impact on the manner in which it celebrates an important event, such as Holy Communion (see Mothlodi 2020:5).

Perhaps, as a start and as Rev. Dr Scholtz (2020) suggested:

We should stop using the language of 'virtual communion' to refer to communion that uses digital platforms to gather and connect the worshiping community, as it implies that the communion they share is not 'real' communion. (p. 4)

The church is in communion, whether there is a pandemic or not, whether people find themselves in lockdown or in complete freedom of movement. The sacrament of Holy Communion celebrates this unity and remains real, whether the context allows for physical presence in its celebration or it prevents people from gathering together in the same spaces.

Considering the tremendous challenges faced by the MCSA on the practice of the sacrament of Holy Communion, and all the inputs provided by the Office of the Presiding Bishop, clergy, academics and laity, the Doctrine, Ethics and Worship Commission of the MCSA drafted the following resolution to be considered by the denomination's highest decision-making body, Conference 2021. I quote the entire resolution, and my apologies for this lengthy quote, but its contents speaks of a real intention to address most, if not all the different arguments discussed in this article. It reads as follows (The Methodist Church of Southern Africa 2021:2-3):

The Methodist Church of Southern Africa, like the Global Ecumenical Body of Christ, finds itself challenged by the extraordinary and unprecedented circumstances precipitated by the global Coronavirus (Covid-19) pandemic. Among other economic and social effects, the pandemic has resulted in local church congregations being prevented from gathering in corporate worship and, as a consequence, receiving Holy Communion.

While the Methodist Book of Order (para. 1.15-1.35) provides the polity, and theological and liturgical foundations for the regular celebration of Holy Communion, no particular provisions are made for practice in times of a pandemic. The incidence of Covid-19 has spurred the Methodist Church of Southern Africa to explore ways to respond creatively within this unique situation while still abiding with the principles and provisions of our polity.
Where context and the Spirit of God demands, we need to adjust our practices in ways that will help the lived faith of the church to adapt and flourish.

In April 2020, the Office of the Presiding Bishop mandated the Doctrine, Ethics and Worship Committee (DEWCOM) to facilitate a theological discussion on Holy Communion in the context of the Covid-19 pandemic. This discussion elicited numerous contributions from Methodist Clergy and Laity, and addressed various issues on Eucharistic theology in relation to our liturgical practice, sacramental living and the socio-economic inequalities that characterise our Connexion. Key to this discussion was the question whether 'online' Holy Communion could be practiced in a way that is consistent with our stated theological understanding of Holy Communion. While diverse responses to this question were articulated, the preponderance of theological opinion concluded that 'online' Holy Communion, within this context, could indeed be practiced with theological integrity, subject to a number of conditions.

1. Noting that:

- The extraordinary and unprecedented circumstances precipitated by the global Covid-19 pandemic has resulted in local church congregations being prevented from gathering in corporate worship for the past few months.

- Notwithstanding the announcement of the resumption of limited public worship services under strict conditions in some of the countries within the Connexion, the nature and likely trajectory of this pandemic is such that many churches and certainly many church members, especially those most vulnerable to infection, will be unable to gather in corporate worship for the foreseeable future.

- The extreme material hardship, emotional trauma, social strain and spiritual isolation that many are enduring in this moment make the sacramental presence of the church and the extension of the means of grace into people's lived experience all the more crucial and urgent.

- The sacrament of Holy Communion is a foundational resource for the life of faith, an imperative of our Lord, and one of the key ways in which our belonging within the body of Christ is affirmed. It also plays a pivotal part in shaping the church's mission and witness in the world, by calling members of the body of Christ to the daily practice of sacramental living.

The Connexional Executive receives the following suggestions from DEWCOM:

- Every Circuit and Society, within the constraints imposed by any pandemics such as Covid-19, and in keeping with our Methodist discipline, should exercise a sacramental presence in life-giving ways that will reach people where they are and meet them in their places of need.

- The Presiding Bishop permits the use of 'online' Holy Communion for a limited time, while the necessity not to gather for public worship in order to avoid the spread of Covid-19 infection endures. For the sake of clarity, 'online' Holy Communion refers to the following: 
A communion service that forms part of a clearly defined and intentional worship gathering of a church community meeting remotely, typically each in their own home, yet connected through the use of some form of digital technology.

2. The celebrant of such a communion service would be an Ordained Minister or Probationer with dispensation who would lead the communion liturgy in the usual way, as per our Methodist practice.

3. This communion liturgy would be shared with the gathered worshipping community through some digital channel, typically a video or audio recording or live feed.

4. Each participating home would have the physical elements of bread and wine present - duly consecrated through the words and actions of the celebrant in the communion liturgy, the active participation in faith of the members of the body of Christ and the agency of the Holy Spirit - which the communicants would share among themselves when invited by the celebrant to do so.

5. The Presiding Bishop grants ordained Methodist Ministers special dispensation to celebrate such 'online' Holy Communion services. Such dispensation will be regarded as temporary and can be revoked by the Presiding Bishop at any time. Such special dispensation will be in force only for as long as public worship services remain inhibited due to pandemics such as Covid-19.

6. In light of the reality that 'online' Holy Communion is accessible only to people who have the privilege of access to the necessary technology and data to participate in such services of Holy Communion, and that many people are excluded by their material and social circumstances from participation in such Holy Communion services:

- People participating in 'online' Holy Communion services are made mindful of those who are excluded from 'online' Holy Communion services and express their solidarity with the needs of all people so excluded.

- People participating in 'online' Holy Communion services are urged to contribute actively and materially to the relief of the needs of the poor as part of their act of worship.

- Prayers of intercession be said before the Passing of the Peace and the Eucharistic Prayer ("The Thanksgiving') for those who are poor, marginalised or excluded for whatever reason from Holy Communion, specifically mentioning those individuals and communities who are nearest to the congregation.

7. DEWCOM, together with the Ecumenical Affairs Unit, inform the Church Unity Commission and other ecumenical partners of this Resolution and engage with them on the theological and practical implications for celebrating 'online' Holy Communion during moments of crisis like Covid-19.

The Connexional Executive notes and affirms the work done by DEWCOM on Sacramental Life in a time of a Pandemic, and refers this discussion document and recommendations to Synods for discussion and reporting to Conference 2021.
In my estimation, this is a sensitive, progressive and practical resolution that paves the way for future generations to be guided on adapting church practices when faced with contexts that are out of the ordinary. Whilst being mindful of the excluded, the practice of online Holy Communion becomes the vehicle through which the church is challenged to facilitate change and healing.

\section{Conclusion}

This article traced the trajectory of the discussion on the practice of Holy Communion in the MCSA during the COVID-19 pandemic lockdown. It observed how the church, as other sectors of society, was caught unawares by the magnitude of the pandemic. This article further engaged the communiques of the Office of the Presiding Bishop, as well as the contributions made by clergy and laity on the practice of Holy Communion using online platforms. It did so, considering the polity of the MCSA and the complications that arise with the practice of online Holy Communion. Furthermore, it observed the shift in emphasis, from a ritual confined to physical space, to the celebration of community. This article then moved to the point of suggesting that more good can come from practicing online Holy Communion than harm. Lastly, this article celebrated the work done by the Doctrine, Ethics and Worship Commission of the MCSA, by taking all contributions and contentions into consideration in formulating a resolution that balances church polity with contextual relevance.

\section{Acknowledgements Competing interests}

The author declares that he has no financial or personal relationships that may have inappropriately influenced him in writing this article.

\section{Author's contributions}

W.B. is the sole author of this research article.

\section{Ethical considerations}

This article followed all ethical standards for research without direct contact with human or animal subjects.

\section{Funding information}

This research received no specific grant from any funding agency in the public, commercial or not-for-profit sectors.

\section{Data availability}

Data sharing is not applicable to this article as no new data were created or analysed in this study.

\section{Disclaimer}

The views and opinions expressed in this article are those of the author and do not necessarily reflect the official policy or position of any affiliated agency of the author. 


\section{References}

Caba, M., 2020, The celebration of the Sacrament of Holy Communion during the time of the COVID-19 pandemic lockdown, Methodist Church of Southern Africa, viewed 11 April 2021, from https://methodist.org.za/wp-content/uploads/2020/05/2005132nd-Round-Holy-Communion-and-COVID19-Mteteli-Caba.pdf.

Carder, K.L., 2009, Living our beliefs: The united Methodist way, Discipleship Resources, Nashville, TN.

Jibiliza, X., 2020, The plight for worship in the midst of coronavirus time formulate distress to Christian religion, Methodist Church of Southern Africa, viewed 11 April 2021, from https://methodist.org.za/wp-content/uploads/2020/05/200520-Theplight-for-worship-Xolisa-Jibiliza.pdf.

Khuzwayo, S., 2020, Does celebrating Holy Communion 'virtually' represent the envisaged community of believers?, Methodist Church of Southern Africa, viewed envisaged community of believers?, Methodist Church of Southern Africa, viewed 2nd-Round-Holy-Communion-and-COVID19-Sifiso-Khuzwayo.pdf.

Kondile, M.P., 2020, Theological views on COVID 19, Methodist Church of Southern Africa, viewed 11 April 2021, from https://methodist.org.za/wp-content/ uploads/2020/05/200520-Theological-views-on-COVID19-Meshack-P-Kondile.pdf.

Magruder, W., 2020, What would Wesley do? Mission and pragmatism in Methodist history, Methodist Church of Southern Africa, viewed 11 April 2021, from https:// methodist.org.za/wp-content/uploads/2020/05/200513-2nd-Round-HolyCommunion-and-COVID19-Wesley-Magruder.pdf.

Malinga, P., 2020a, Communique: MCSA response to Covid-19, Methodist Church of Southern Africa, viewed 11 April 2021, from https://methodist.org.za/ communique-mcsa-response-to-covid-19/.

Malinga, P., 2020b, Communique 4, Methodist Church of Southern Africa, viewed 11 April 2021, from https://methodist.org.za/wp-content/uploads/2020/03/ Communique-4-MCSA-Response-to-Covid-19.pdf.

Malinga, P. \& Hansrod, M., 2020, Statement to all ministers and members of the Methodist Church of Southern Africa, Methodist Church of Southern Africa viewed 11 April 2021, from https://methodist.org.za/wp-content/ uploads/2014/10/D1-Statement-to-all-ministers-and-members-of-theMethodist-Church-of-Southern-Africa-1.pdf.

Marumo, P., 2020, COVID-19 and Kenosis: Where is the place of faith?, Methodist Church of Southern Africa, viewed 11 April 2021, from https://methodist.org.za/wp-content/ uploads/2020/05/200520-COVID-19-and-Kenosis-Dr-Phemelo-Marumo.pdf.

Methodist Conference Office, 1975, The Methodist service book, Methodist Publishing House, Peterborough.

Moeketsi, P., 2020, The economic impact of COVID 19: A potential to press the restart button?, Methodist Church of Southern Africa, viewed 11 April 2021, from https:// methodist.org.za/wp-content/uploads/2020/06/200610-Economy-and-COVIDmethodist.org.za/wp-content/uplo
Mokgothu, R.S., 2020, email, 17 April 2020, bishop@mcsalimpopo.co.za.

Molo, M., 2020, Holy Communion as a consequence of COVID-19 experience: $A$ perspective, Methodist Church of Southern Africa, viewed 11 April 2021, from https://methodist.org.za/wp-content/uploads/2020/05/200513-2nd-RoundHoly-Communion-and-COVID19-Mzwandile-Molo.pdf.

Mostert, M., 2020, Communion and Uber Eats - Managing the Methodist grace supply chain during Covid-19 lockdown, Methodist Church of Southern Africa, viewed 11 April 2021, from https://methodistorg.za/wp-content/uploads/ 2020/05/200513-2nd-Round-Holy-Communion-and-COVID19-Dr-MartinMostert.pdf.

Mothlodi, S., 2020, COVID-19; Shaking the context and creating a new way of doing church. A missiological reflection, Methodist Church of Southern Africa, viewed 11 April 2021, from https://methodist.org.za/wp-content/ uploads/2020/05/200520-Missiological-reflection-on-doing-churchSethunya-Mothlodi.pdf.

Olivier, W., 2020, e-Holy Communion and the Methodist view, Methodist Church of Southern Africa, viewed 11 April 2021, from https://methodist.org.za/wpcontent/uploads/2020/05/200513-2nd-Round-Holy-Communion-and-COVID19Content/uploads/202

Scholtz, R., 2020, Communion during lockdown: Some pastoral and theological reflections, Methodist Church of Southern Africa, viewed 11 April 2021, from reflections, Methodist Church of Southern Africa, viewed 11 April 2021, from https://methodist.org.za/wp-content/uploads/202
Holy-Communion-and-COVID19-Roger-Scholtz.pdf.

Silolo, X.,2020, Reflection on virtual Holy Communion in the MCSA, Methodist Church of Southern Africa, viewed 11 April 2021, from https://methodist.org.za/wpcontent/uploads/2020/05/200513-2nd-Round-Holy-Communion-and-COVID19content/uploads/202
Xolisani-Silolo.pdf.

South African Council of Churches, 2020, SACC statement on churches in COVID Christmas, Methodist Church of Southern Africa, viewed 11 April 2021, from https://methodist.org.za/wp-content/uploads/2020/12/SACC-Statement-onChurches-in-COVID-Christmas_FINAL.pdf.

Stamm, M.W., 2006, Let every soul be Jesus' guest: A theology of the Open Table, Abingdon Press, Nashville, TN.

Tapula, K., 2020, Sterilising mission: Having church in the post-Covid era, Methodist Church of Southern Africa, viewed 11 April 2021, from https://methodist.org.za/ wp-content/uploads/2020/05/200701-Sterilizing-Mission-Having-church-in-thepost-covid-era-Dr-Kanyiso-Tapula.pdf.

The Methodist Church of Southern Africa, 2016, The Methodist book of order: The laws and discipline of the Methodist Church of Southern Africa, Methodist Publishing House, Cape Town.

The Methodist Church of Southern Africa, 2021, Resolutions referred to Synods 2021 from the Connexional Executive 2020, Report sent to clergy of the MCSA, Johannesburg. 